\title{
A better class of heckle
}

\section{Helen Pilcher on the rise of science comedy.}

$\mathrm{T}$ en years ago, jokes about science were as elusive as the Higgs boson. Times are changing. From fresh-faced wannabes to headline acts, more comedians are finding humour in the scientific endeavour. Add in the Ig Nobel prizes - the US awards for inherently funny research, which celebrate their twentieth anniversary this week - and science, it seems, has never been so amusing. Humour can make science accessible, but look closer and cultural peculiarities emerge.

Britain is in the vanguard of science comedy, with a crop of shows infiltrating this year's festivals, from the Royal Society's recent See Further celebration in London to the Edinburgh Festival Fringe. Global audiences are not far behind, as the geeky references in successful television series such as The Simpsons and The Big Bang Theory attest.

The comedic potential of particle accelerators or neurotransmission may not be obvious, but in the right hands they can be a recipe for mirth. And science has its own cast of wacky characters - from bongo-playing physicist Richard Feynman to gold-nosed astronomer and moose owner Tycho Brahe.

"There are a lot of intelligent, well-read comedians out there who are interested in science and who want to share their passions," says British comedian and science enthusiast Robin Ince. 'Reading-list comedy', as Ince calls it, is part of a new strain that is unashamedly intellectual, leaving audiences clamouring for an encore and a bibliography. "Science comedy is the new alternative comedy, he says.

Ince has created and compèred Nine Lessons and Carols for Godless People, a Christmas variety show that celebrates science and reason with a mix of science-themed stand-up, mini lectures and musical acts. The show, which

I GNOBLE WORK Founder's favourites

Physics (2003): An analysis of the forces required to drag sheep over various surfaces.

Biology (2003): The first documented case of homosexual necrophilia in the mallard duck.

Biology (2002): A study of the

courtship behaviour of ostriches towards humans under farming conditions in Britain.

Technology (2001): The Australian patenting of the wheel.

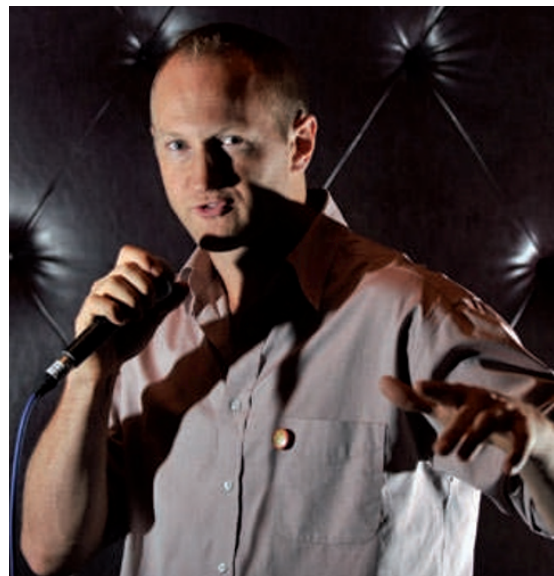

Baba Brinkman raps on human behaviour.

has included evolutionary biologist Richard Dawkins and comedian Ricky Gervais, sold out on its 2008 debut run in London and returns for a third season this December.

Each comedian weaves science into their routine in their own way. Some point out the bizarre side of evolutionary theory or the human genome - did you know there is a gene for gullibility? Canada's Baba Brinkman takes a lyrical approach with his Rap Guide to Human Nature. Others adopt a sceptical stance, debunking pseudoscience and dressing down its practitioners. "The great thing about homeopathy is that you can't overdose on it - but you can drown," quips Irish comedian and physics graduate Dara O’Briain.

\section{THE BRIGHT CLUB}

Good comics tailor jokes to their audiences. Playing at colleges and conferences where the crowd shares a love of science, US comedian Brian Malow uses lines that are deliberately knowing: "Schrödinger's cat walks into a bar ... and doesn't." But he admits such gags fall flat in mainstream comedy clubs. In Britain, science comedy seems to have reached a broader audience - research-related quips can be found on mainstream TV panel games and radio programmes as well as on stage.

The proliferation of science and arts festivals is fostering the genre. "Comedy can be used to make science more approachable and broadens the festival audience," says Sharon Bishop, executive director of the Cheltenham Science Festival, which has booked comedy acts since its launch in 2002. Comedian and writer Timandra Harkness agrees. With mathematician and stand-up Matt Parker, she performed their comedy show on statistics and health, Your Days Are Numbered - The
Maths of Death, to packed audiences last month at the Fringe. "There was a real appetite for comedy with an intellectual content," Harkness says.

But the fashion for science comedy is by no means international. "America has some of the world's finest scientists and finest comedians, but the two have yet to overlap," says Malow. Reasons may include the tensions between science and faith in the United States, and the relative dearth of science festivals, making interested audiences harder to find. Events are on the increase, however - Malow will play the inaugural USA Science \& Engineering Festival this autumn in Washington DC.

Universities, too, are embracing comedy for enhancing communication skills. At the Bright Club, a monthly variety night organized by University College London, staff and students write and perform comedy about their research. The scheme, launched in May 2009, has spawned spin-off clubs in Manchester and Cardiff.

"It's all very encouraging," says UK anatomist and broadcaster Alice Roberts, who is concerned that scientists are often perceived as separate from culture. Science is part of our everyday lives, so attempts to root it in a cultural context are welcome. Science comedy, she argues, helps humanize science.

The Ig Nobels have the same goal (see 'Ignoble work'). By pointing out absurdities in research, the awards aim to make science and scientists seem fallible. "For a long time, science has been treated as something that's very important, serious and definitely not funny. It shouldn't be like that," says Marc Abrahams, originator of the Ig Nobels and editor of the Annals of Improbable Research. It took just ten people to plan and judge the first tranche of awards in 1990. Now some 250 help to whittle the 7,000 or so nominations down to ten lucky winners and plan the uproarious award ceremony at Harvard University.

Honouring as they do "science that makes you laugh, and then makes you think", Ig Nobels are just as likely to go to mediocre research as top-notch science. But research that seems silly is often relevant to the real world - the 2003 prize for physics, 'An analysis of the forces required to drag sheep over various surfaces', revealed a more ergonomic floor for shearing.

Science comedy may be funny, clever and pro-rationalist, but so too is its audience. "We like to think we get a better class of heckle at our shows," says Harkness, whose recent Edinburgh gig was interrupted with cries of "What exactly does the $y$-axis represent?" Comedians beware: heckling, too, is becoming more intellectual.

Helen Pilcher is a science writer and comedian. She is one-half of The Comedy Research Project, a science-comedy show. e-mail:helenpilcher@googlemail.com 